\title{
Feasibility study of wind farms: A case study for Izmir, Turkey
}

\author{
Baris Ozerdem*, Serra Ozer, Mahir Tosun \\ Department of Mechanical Engineering, Izmir Institute of Technology, Gulbahce 35430 Urla-Izmir, Turkey
}

Received 25 March 2005; received in revised form 5 October 2005; accepted 24 February 2006

Available online 18 April 2006

\begin{abstract}
Wind is one of the world's fastest growing renewable energy sources. The rapid growth in wind power is a result of improvements accomplished in technology. This paper presents the technical and economical feasibility of wind farms. The method is applied to a potential wind farm site located in Izmir, Turkey. The site is considered on technical and economical parameters for the complete plant and its running costs. For technical consideration wind speed, prevailing wind direction, and temperature measurements are performed. For economical consideration, three different scenarios namely, autoproducer, autoproducer group, and independent power producer (IPP) cases, are investigated and compared with respect to net present value (NPV), internal rate of return (IRR), and pay back period (PBP) criteria. The study indicates the costs of generated energy by wind turbines with different characteristics as a function of the installed capacity. It is concluded that, the larger the installed capacity, the smaller the generating cost per $\mathrm{kWh}$. The generating cost was calculated as low as $2.68 \mathrm{UScent} / \mathrm{kWh}$ for the $I P P$ scenario. The profitability analysis also shows that, larger installed capacity with larger rated power wind turbines present higher $I R R$ of the investment. The sensitivity analysis backs up the findings.
\end{abstract}

(C) 2006 Elsevier Ltd. All rights reserved.

Keywords: Wind energy; Wind turbines; Techno-economic feasibility

\footnotetext{
*Corresponding author. Tel.: + 902327507801 ; fax: + 902327507890 .

E-mail address: barisozerdem@iyte.edu.tr (B. Ozerdem).
} 


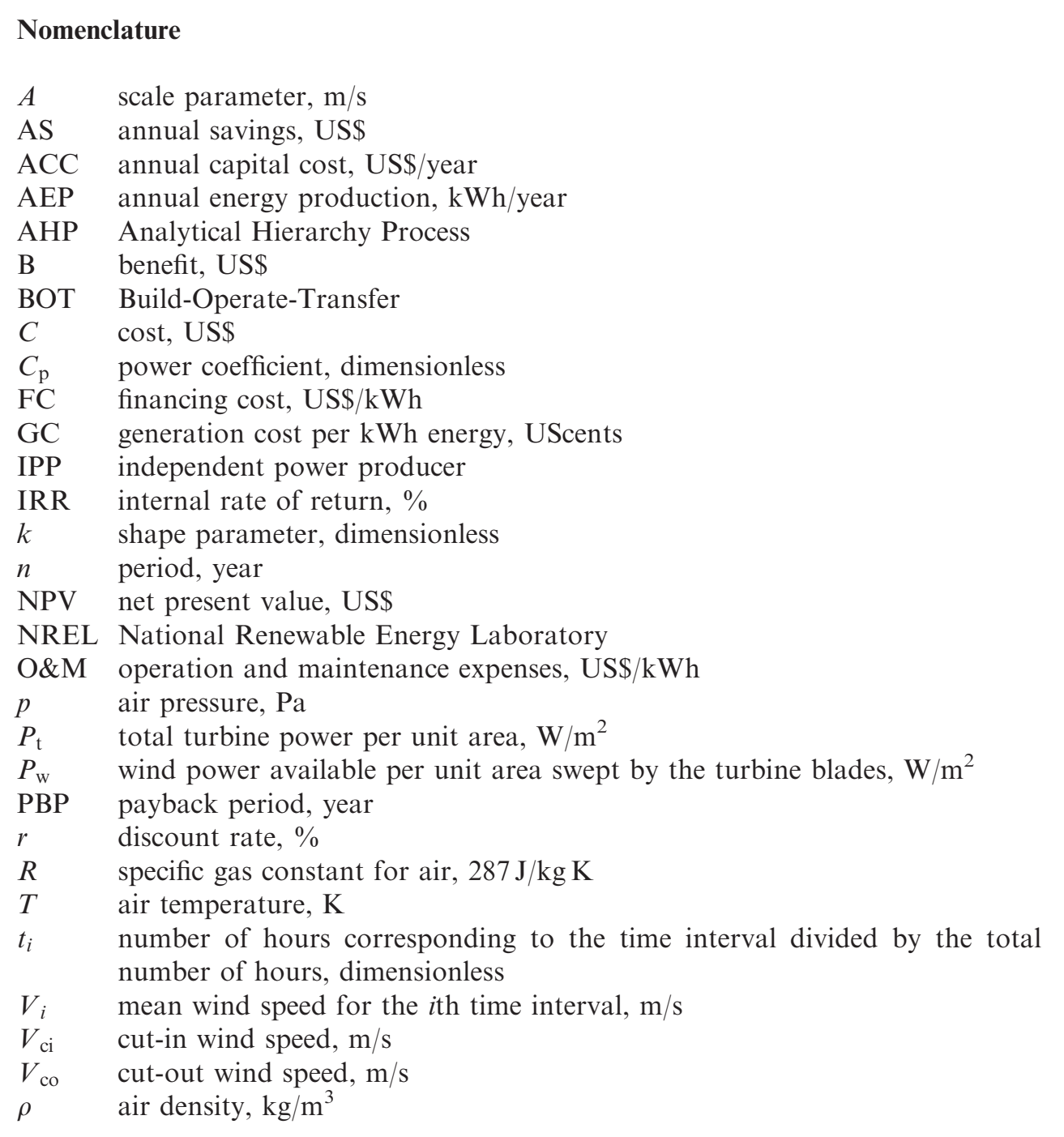

\section{Introduction}

Technology of the extraction of power from wind with modern turbines is a wellestablished industry, at present. In parallel, the wind energy applications are growing rapidly, either, as off-shore or on-shore wind energy systems throughout the world. Improvements in high strength fiber composites, power electronics, and generators are the main contributors to this growth. The results of improved efficiency and reduced unit cost of wind turbines make wind power generation competitive to that of conventional sources. Furthermore, the wind power has an additional advantage of being a non-polluting source of energy. 
Developing a utility-scale wind project is a complicated and time-consuming process involving developers, landowners, utilities, the public and various local authorities. Although each wind energy project is unique and have different characteristics, basic features and related steps are common.

In practice, the steps are iterative and overlap one another depending on the specific project circumstances. The key steps of development and planning for a wind farm are site selection, detailed wind assessment, feasibility, construction and operation [1]. The most important factor to be considered in a wind energy plant is the site's wind resource. Availability and access to existing power lines should be considered in selecting a site, as well. A site is selected for further investigation if the preliminary study reveals promising potential and an absence of major environmental and technical constraints. Later, at least one-year site-specific data of wind measurements are required to determine energy potential. The purpose of this phase is to identify areas with high-energy yield. A feasibility study includes an economic assessment to establish the commercial viability of the project. An economic analysis is needed both for developers and financiers. Construction of a wind farm normally begins with grading and laying out the access roads that run to wind turbines. After completing concrete foundations for the turbine towers and auxiliary structures, electricity cables for underground and overhead collection systems are installed. Next activity includes assembling and erecting the tower, mounting the nacelles, and attaching the rotors. The continuous safe operation of a wind farm throughout the project life is in responsibility of developers, owners, and operators. Wind energy is a capitalintensive technology with low-operating and zero-fuel costs.

Several studies have been carried out on the technical and economical assessment of offshore/on-shore wind farms [2-8]. Pantaleo et al. [2] have concluded that large wind farm investments present internal rate of return (IRR) value of $27 \%$, in the technical and economical feasibility study of off-shore wind farms in the Region of Puglia, Italia. Stocton [3] has revealed that wind farm delivers electricity at a price $34 \%$ less than residual fueled generation, in an economic feasibility study of a utility-scale wind farm in Hawaii, USA. El-Sayed's study [4] has indicated that the cost/benefit analysis would be less than unity for a planned wind farm in Za'afarana, Egypt. Marafia and Ashour [5] has presented that the cost of electricity generation from the wind which can be as low as $0.0289 € / \mathrm{kWh}$ compares favorably to that from fossil fuel resources, in the potential and economical feasibility study adopting wind energy in Qatar. El-Osta and Kalife [6] have demonstrated that the proposed wind farm in Zwara, Libya was economically feasible for the different wind turbine sizes of 0.6, 1, and 1.5 MW. Cavallaro and Ciraolo [7] have shown that the wind farm located in the island of Salina, Italia was an attractive and realistic option. An integrated time-depending feasibility study on behavior of wind farms in Greece has concluded that the electricity price escalation and inflation rates are the most important parameters of the feasibility analysis [8]. These studies' common aim was to predict energy production and investigate cost related issues by selecting areas which are suitable for wind energy development projects.

The purpose of this study is to give an overview on the technical and economical evaluation of wind farms by showing an application as a choice. A few years ago, some steps were taken to initiate a wind farm project on the campus area of Izmir Institute of Technology, Turkey. The main objective was to generate the electricity need of the campus buildings. Then, the study is enlarged and the scenarios were diversified including becoming an independent power producer (IPP). This case study starts with finding the 
maximum capacity, which can be installed on the campus with consideration of grid constraint and accessibility. Economic analysis was done for three alternative scenarios. The methodology used for evaluating the expected annual energy yield, the cost and profitability of the investment, the cost of produced unit energy on the basis of siting parameters and electricity sales price, was applied to this case study. In the economic analysis, fixed and variable costs were compared with the investment cost of wind farm. Lastly, sensitivity and variance analysis were done for the three scenarios.

The wind measurement results confirm that the investigated site can be classified as excellent, in terms of wind energy potential. In addition, the financial parameters for the complete plant and its operational costs indicated that the most cost-effective scenario was $I P P$ case in terms of the cost of a $\mathrm{kWh}$ energy generated by wind turbines with different characteristics.

\section{Wind energy status}

\subsection{Global status of wind energy}

World's primary energy consumption has been increased by $2.6 \%$ in 2002 , ahead of the 10 -year growth trend of $1.4 \%$ per annum [9]. Despite their potential, the contribution of renewable energies to world energy supplies is still modest. Renewable energies are estimated to supply about $17 \%$ of world primary energy at present [10]. But, most of this is from hydro-power. The other renewable energies such as solar, biomass, and wind contribute a much smaller proportion of energy needs (e.g. about $3 \%$ of electricity and $2 \%$ of primary energy) at present [11].

Since wind energy is currently viewed as one of the most promising renewable energy resource, the growth is relatively high. Cumulative global wind energy generating capacity was reached $47,317 \mathrm{MW}$ by addition of worldwide installed new equipment totaling $7976 \mathrm{MW}$ at the end of 2004 [12]. The growth is expected to continue into the next decade, as well. Although about 50 countries around the world contribute to the global total, Europe accounts for $72.4 \%$ of the current total capacity especially Germany, Spain, and Denmark represent the fastest growth coming from Europe. The policy for the promotion of renewable energy resources has been influenced by international obligations. Kyoto Protocol is a good example for these obligations at the global level.

\subsection{Wind energy in Turkey}

Turkey is a rapidly growing country, both in economic and population sense, with $8.5 \%$ economic growth rate and $1.5 \%$ population growth rate. In parallel, it is one of the fastest growing energy markets in the world. In 2004, the total installed and production capacity of power plants increased to 37,381.6 MW and 149,608.3 GWh, respectively [13]. Turkey has a considerable potential for electricity generation from wind. A study carried out in 2002 concluded that Turkey has a theoretical wind energy potential of nearly $90,000 \mathrm{MW}$ and an economical wind energy potential of about 10,000 MW. The most promising region is in northwest Turkey [14]. Although Turkey has large amount of wind potential, the installed wind energy capacity is only $19.2 \mathrm{MW}$ at present. The first wind farm was commissioned in autoproducer status in 1998, following the privatization activities, which allowed the domestic and foreign private sectors to invest in the energy sector in 1984. The 
other two wind farms, which commissioned between 1998 and 2000 were established under Build-Operate-Transfer (BOT) model. The total annual wind energy produced from these three wind farms is about $65,000,000 \mathrm{kWh}$.

\section{Technical and economical aspects of wind farms}

Developer should focus on the selected site's further suitability and availability in feasibility phase of the wind energy project. Site characteristics, in particular, detailed technical assessment including on-site wind monitoring, natural constraints and grid connection, and a detailed economic assessment are the main elements considered and investigated during a feasibility study.

\subsection{Technical aspects}

Actual site measurements such as wind speed, wind direction, and temperature are vital for the wind project [15]. Multiple wind speed measurement heights are encouraged for determining wind shear characteristics of a site. Since the energy contained in the wind is directly proportional to the cubic wind speed, the measurements as close as possible to the hub height of a wind turbine is crucial. But, typical wind measurement heights are 10 and $30 \mathrm{~m}$.

Wind power density is a good indication of a site's wind energy potential. This value combines the effect of wind speed distribution and its dependence on wind speed and air density. The wind power available per unit area swept by the turbine blades is given as the following equation:

$$
P_{\mathrm{t}}=0.5 \rho C_{\mathrm{p}} \sum\left(V_{i}^{3} t_{i}\right)
$$

where $V_{i}$ is the mean wind speed for the $i$ th time interval (e.g. 10-min or hourly basis), $t_{i}$ the number of hours corresponding to the time interval divided by the total number of hours, $C_{\mathrm{p}}$ is a power coefficient provided by the wind turbine manufacturer, and $\rho$ the air density and can be calculated from the following equation:

$$
\rho=p / R T,
$$

where $p$ is the air pressure $(\mathrm{Pa}), R$ the specific gas constant for air $(287 \mathrm{~J} / \mathrm{kg} \mathrm{K})$, and $T$ the air temperature $(K)$.

A wind turbine generates power between cut-in wind speed, $V_{\mathrm{ci}}$, and cut-out wind speed, $V_{\text {co. }}$. Wind turbine output between rated wind speed, $V_{\mathrm{r}}$, and the cut-out wind speed is usually constant.

After recording on-site data for at least 1 year and using topographical data, wind characteristics and power extraction can be predicted by using special modeling softwares mapping potential energy yield over the site. Energy map helps developer to find the area, which would give maximum output.

A geotechnical study conducted to determine soil stability, foundation requirements, drainage and potential erosion problems and a network analysis conducted to determine the impacts of embedding the wind farm onto the grid should also be considered in technical assessment duration.

There are some advanced mesoscale wind resource-mapping techniques that combines numerical weather and wind flow models with a variety of weather data and terrain 
features such as height variation, roughness and sheltering obstacles [16]. A number of well known commercially available softwares such as WindPro [17], WAsP [18] and MesoMap [19] use these techniques to develop wind resource maps in order to produce statistical results and wind resource map. WindPro software is used as an analysis tool for this study. A digital map of the site, weather data and terrain features are the main inputs of this software. The statistical results consist of wind speed, prevailing wind direction and wind energy distributions.

\subsection{Economical aspects}

The cost of generating electricity in a wind farm has three main components: capital cost, operation and maintenance costs, and financing cost. Absence of fuel cost is a distinct characteristic of renewable energy sources such as wind. The unit energy generation costs are slightly affected, once the wind farm is built. Hence, the economics of wind energy is very sensitive to capital cost. Investors want to maximize the profit. In other words, minimizing the cost is a method for achieving this goal. Generation cost per $\mathrm{kWh}$ energy, $\mathrm{GC}$, can be determined from the following expression:

$$
\mathrm{GC}=\mathrm{ACC} / \mathrm{AEP}+\mathrm{O} \& \mathrm{M}+\mathrm{FC},
$$

where ACC is the annual capital cost (US\$/year), AEP the annual energy production (kWh/year), O\&M the operation and maintenance expenses (US\$/kWh) and FC the financing cost (US\$/kWh).

The project developers concern with cash flow and consider all money flowing in as positive and all money flowing out as negative. They are interested in net benefits and net present values (NPV) in comparison to the value of their investment. The financer's point of view is different from a developer. The financers evaluate the return on total investment, which includes equity plus loan and consider its profitability. Despite the difference, the important aim, for all parties, is to ensure that the project is the cost-effective alternative for attaining the required output.

Cost-effective solution means the most suitable alternative, technically and economically. The essential criteria, which may lead to safe conclusions with respect to the economics are NPV, IRR, and payback period (PBP). Projects in the electricity supply industry live for a long time. In parallel, wind farms last for about 25 years. Therefore, the time value of money becomes highly important for capital-intensive long life projects such as wind farms.

NPV is a powerful indicator of the viability of the projects and can be determined from the following relation:

$$
\mathrm{NPV}=\sum(B-C) /(1+r)^{n},
$$

where NPV is the net present value, $B$ the benefit, $C$ the cost, $n$ the period and $r$ the discount rate. The greater the NPV of a project, the more profitable it is.

IRR is also a popular and widely used method for the evaluation of projects. The IRR is discount rate " $r$ " which equates two streams of costs and benefits. Alternatively, it is the rate, which would make NPV value equal to zero.

$$
\sum\left[C /(1+r)^{n}\right]=\sum\left[B /(1+r)^{n}\right] .
$$


A common and simple way to evaluate the economic merit of an investment is to calculate its PBP or, in other words, break-even time. This value is usually measured in years and shows amount of time to recover the total investment.

$$
\mathrm{PBP}=C / \mathrm{AS}
$$

where AS is the annual savings.

Variance analysis is an analysis of the variables that have contributed to the outcome of the IRR, NPV and break-even time values. Variance analysis can be carried out for both costs and revenues.

\section{Case Study}

\subsection{Description of the site}

Successful wind farm development depends on good location. Location dictates three key factors: wind energy output, grid availability and construction conditions. The proposed site is on the campus area of Izmir Institute of Technology, which is located in Urla county, Izmir. The site selection was done by using Analytical Hierarchy Process (AHP) method, which takes the sites wind power potential and accessibility to roads and power transmission lines into consideration as decision criteria [20]. Fig. 1 shows the aerial view of the site.

Wind data were collected by two masts located on different coordinates on the site between July 2000 and January 2003. They all had two anemometers at 10 and $30 \mathrm{~m}$

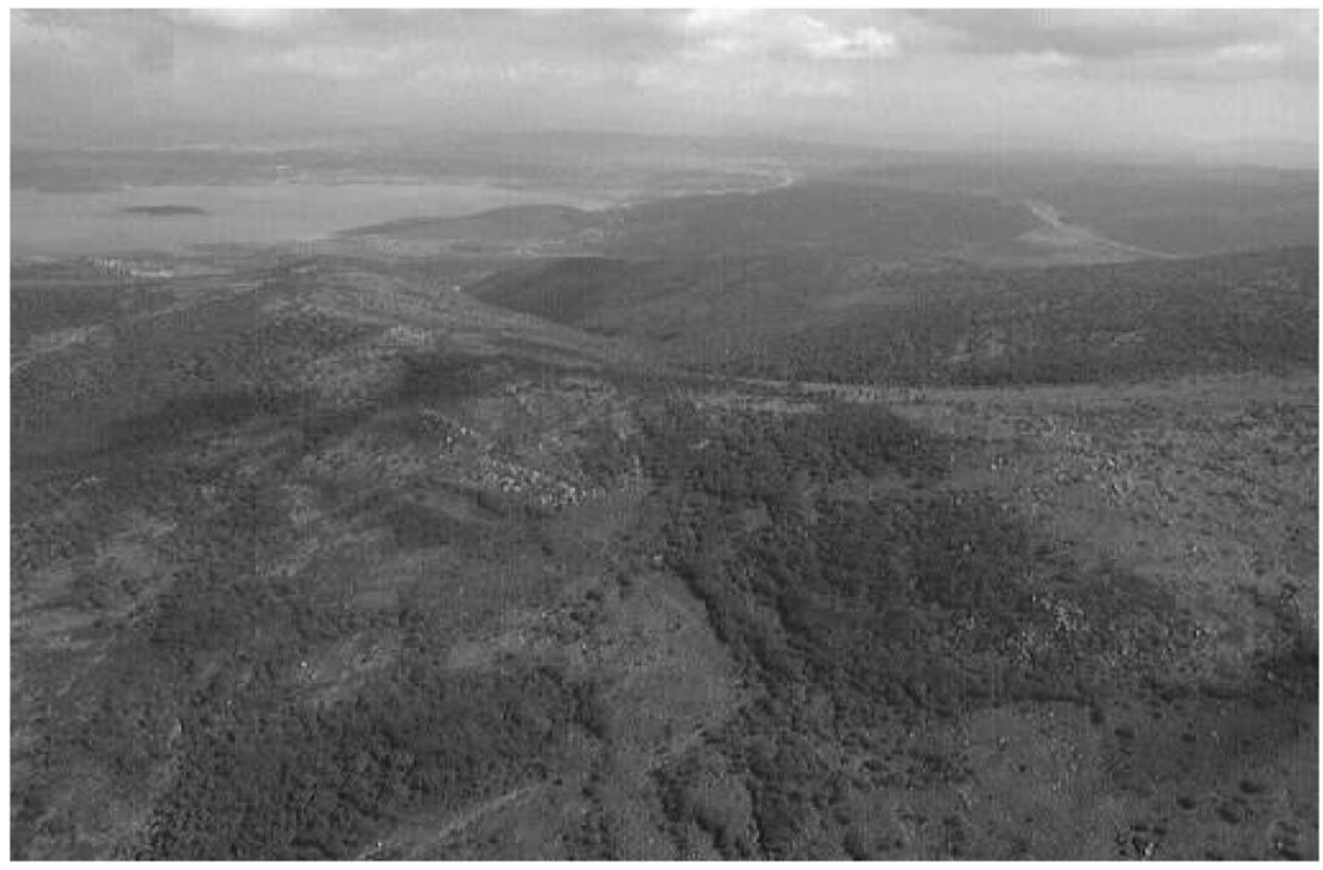

Fig. 1. Aerial view of the site 
heights and a wind vane at $30 \mathrm{~m}$ height of the mast, which was constructed as tabular tower. Temperature, humidity, and atmospheric pressure data were also obtained during the monitoring period. These data were collected with a rate of 144 observations per day using 10-min time interval.

\subsection{Wind field modeling}

Collected data were evaluated by WindPRO software [17] for wind statistics. Fig. 2 shows mean monthly variation of measured wind speeds. The wind speed variations are best described by the Weibull probability distribution function with two parameters, namely, $k$ as shape parameter and $A$ as scale parameter. Table 1 shows the Weibull data corresponding to 12 sectors. Weibull distributions for measured wind speeds at two prevailing directions of north (N) and north-northeast (NNE) and total one representing all sectors are given in Fig. 3.

Wind energy map in Fig. 4 indicates excellent zones corresponding to the Class 6 of National Renewable Energy Laboratory (NREL) standards [15]. Four site locations were selected which have mean wind speed of $7.9 \mathrm{~m} / \mathrm{s}$ at $30 \mathrm{~m}$ height to install wind turbines, virtually. Due to the availability of land and cost-effective grid connection, the wind farm power capacity was revised. The nearest substation is in Urla county. It is connected to $154 / 34.5 \mathrm{kV}$ line with $25 \mathrm{MVA}$ transformer power. The short-circuit power at the network nodes was calculated as $238 \mathrm{MVA}$. Accordingly, the maximum capacity which could be connected to $34.5 \mathrm{kV}$ line was calculated as $12 \mathrm{MW}$ at most.

\subsection{Economic analysis}

The economic analysis of the project was conducted by using RETScreen software [21]. The analysis was performed for turbines having different rated power capacities. Table 2, shows the technical data of wind turbines used in the study. The cost-related data were taken from Ref. [22], as well.

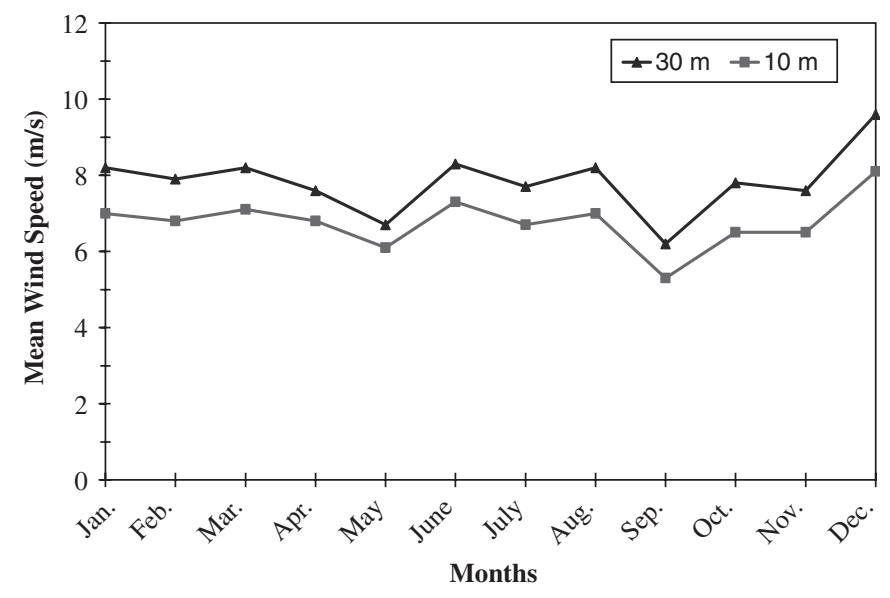

Fig. 2. Mean monthly variation of measured wind speeds. 
Table 1

Weibull data corresponding to 12 sectors for $30 \mathrm{~m}$ height

\begin{tabular}{lccccc}
\hline Sector & A-parameter $(\mathrm{m} / \mathrm{s})$ & Mean wind speed $(\mathrm{m} / \mathrm{s})$ & $k$-parameter & Frequency $(\%)$ & Wind shear \\
\hline N & 10.41 & 9.25 & 2.69 & 28.40 & 0.16 \\
NNE & 9.22 & 8.19 & 2.52 & 13.00 & 0.18 \\
ENE & 5.85 & 5.25 & 1.57 & 3.90 & 0.11 \\
E & 6.39 & 5.69 & 1.72 & 4.20 & 0.12 \\
ESE & 9.57 & 8.49 & 1.95 & 5.40 & 0.11 \\
SSE & 9.82 & 8.71 & 1.92 & 9.30 & 0.16 \\
S & 9.32 & 8.26 & 1.97 & 7.40 & 0.15 \\
SSW & 7.99 & 7.10 & 1.83 & 7.40 & 0.13 \\
WSW & 6.34 & 5.75 & 1.45 & 2.70 & 0.11 \\
W & 6.43 & 5.72 & 1.75 & 5.30 & 0.08 \\
WNW & 6.69 & 5.93 & 2.01 & 6.40 & 0.00 \\
NNW & 8.54 & 7.59 & 2.69 & 60 & 0.12 \\
\hline
\end{tabular}

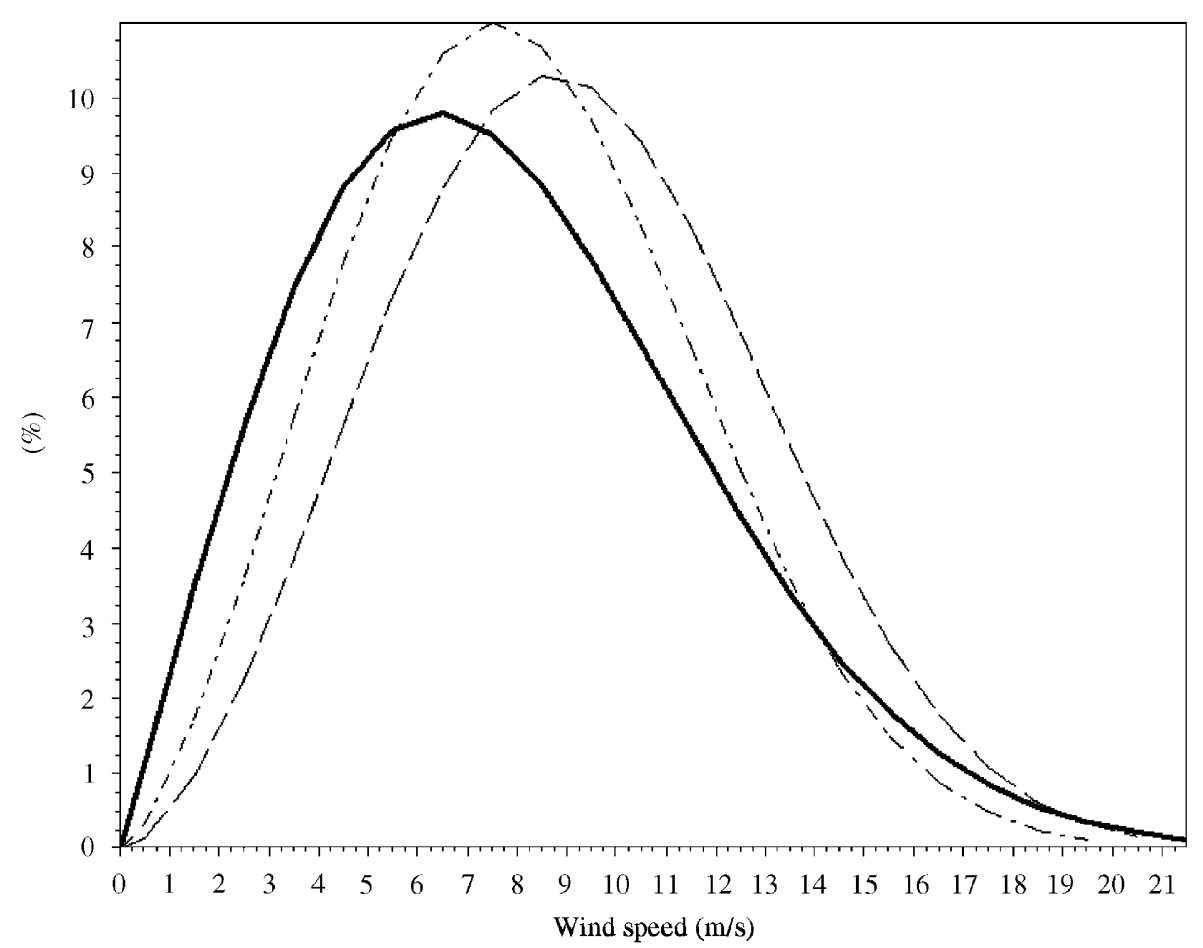

Total A: $8,9 \mathrm{~m} / \mathrm{s} \mathrm{k}: 2,05 \mathrm{Vm}: 7,9 \mathrm{~m} / \mathrm{s} \quad-$ - N A: $10,4 \mathrm{~m} / \mathrm{s} \mathrm{k}: 2,69 \mathrm{Vm}: 9,3 \mathrm{~m} / \mathrm{s}$
— - - NNE A: $9,2 \mathrm{~m} / \mathrm{s} \mathrm{k}: 2,52 \mathrm{Vm}: 8,2 \mathrm{~m} / \mathrm{s}$

Fig. 3. Weibull distributions for measured wind speeds at two prevailing directions (N and NNE), and total one representing all sectors for $30 \mathrm{~m}$ height.

The study covers three scenarios. First scenario was to build a farm, which provides the energy of the Institute in autoproducer status. Second scenario was an autoproducer group project including another facility besides the Institute. Third scenario was an IPP case. The 


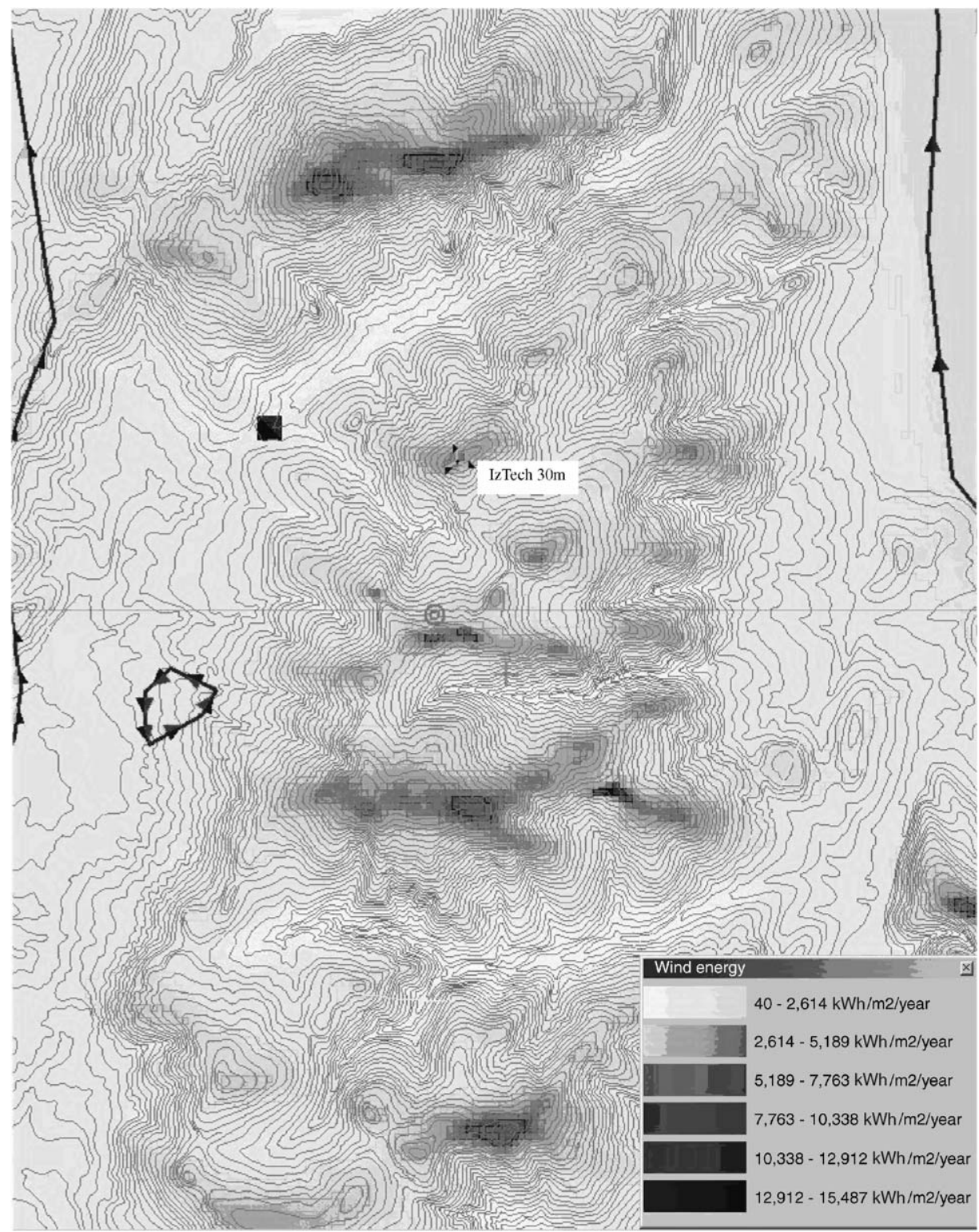

Fig. 4. Wind energy map of the site.

analysis was conducted for project life of 25 years, debt ratio of $70 \%$, debt term of 10 years, discount rate of $15 \%$. Since the Institute owned the land, this cost was not included in the economic analysis. Tax and insurance related issues, also, were not included in order to make the analysis less complicated.

\subsubsection{Autoproducer case}

The total electricity consumption of the Institute was determined as 3,200,000 kWh/year. For this scenario four wind turbine alternatives with $600,900,1000$ and $1500 \mathrm{~kW}$ rated 
Table 2

Technical data of wind turbines used in the study

\begin{tabular}{llllllll}
\hline Wind turbine type & $\begin{array}{l}\text { Rated } \\
\text { output } \\
(\mathrm{kW})\end{array}$ & $\begin{array}{l}\text { Cut-in } \\
\text { speed }(\mathrm{m} / \mathrm{s})\end{array}$ & $\begin{array}{l}\text { Cut-out } \\
\text { speed }(\mathrm{m} / \mathrm{s})\end{array}$ & $\begin{array}{l}\text { Rated } \\
\text { speed } \\
(\mathrm{m} / \mathrm{s})\end{array}$ & $\begin{array}{l}\text { Hub } \\
\text { height } \\
(\mathrm{m})\end{array}$ & $\begin{array}{l}\text { Rotor } \\
\text { diameter }(\mathrm{m})\end{array}$ & $\begin{array}{l}\text { Expected } \\
\text { life }(\mathrm{years})\end{array}$ \\
\hline Enercon E40 & 600 & 2.5 & $28-34$ & 12 & 50 & 44 & 25 \\
Neg Micon NM52 & 900 & 3.5 & 25 & 16 & 61.5 & 52.2 & 25 \\
Enercon E-58/10.58 & 1000 & 2.5 & $28-34$ & 12 & 70 & 58.6 & 25 \\
Neg Micon NM64C & 1500 & 4 & 25 & 14 & 68 & 64 & 25 \\
Enercon E-66 & 1800 & 2.5 & $28-34$ & 12 & 65 & 70 & 25 \\
\hline
\end{tabular}

Table 3

Capital cost break down for autoproducer scenario (US\$)

\begin{tabular}{|c|c|c|c|c|c|c|c|c|c|c|}
\hline \multirow{2}{*}{$\begin{array}{l}\text { WECS } \\
\text { Item }\end{array}$} & \multicolumn{2}{|l|}{$0.6 \mathrm{MW}$} & \multicolumn{2}{|l|}{$0.9 \mathrm{MW}$} & \multicolumn{2}{|l|}{$1 \mathrm{MW}$} & \multicolumn{2}{|l|}{$1.5 \mathrm{MW}$} & \multicolumn{2}{|l|}{$1.8 \mathrm{MW}$} \\
\hline & Cost & $\%$ & Cost & $\%$ & Cost & $\%$ & Cost & $\%$ & Cost & $\%$ \\
\hline Equipment & $1,349,680$ & 61.74 & 921,260 & 54.09 & $1,437,604$ & 64.02 & $1,546,240$ & 65.42 & $2,099,540$ & 71.31 \\
\hline Feasibility & 40,600 & 1.86 & 40,600 & 2.38 & 40,600 & 1.81 & 40,600 & 1.72 & 40,600 & 1.38 \\
\hline Development & 157,000 & 7.18 & 157,000 & 9.22 & 157,000 & 6.99 & 157,000 & 6.64 & 157,000 & 5.33 \\
\hline Engineering & 36,100 & 1.65 & 36,100 & 2.12 & 36,100 & 1.61 & 36,100 & 1.53 & 36,100 & 1.23 \\
\hline Balance of plant & 512,000 & 23.42 & 476,000 & 27.95 & 481,000 & 21.42 & 486,000 & 20.56 & 491,000 & 16.68 \\
\hline Miscellaneous & 90,815 & 4.15 & 72,238 & 4.24 & 93,092 & 4.15 & 97,638 & 4.13 & 119,970 & 4.07 \\
\hline
\end{tabular}

Table 4

Summary of all alternatives for IZTECH autoproducer scenario

\begin{tabular}{lllll}
\hline IZTECH autoproducer & 1 & 2 & 3 & 4 \\
\hline Turbine-rated power(kW) & 600 & 900 & 1000 & 1500 \\
Manufacturer/turbine type & Enercon E40 & NEG-Micon NM52 & Enercon E58 & NEG-Micon NM64 \\
Number of turbines & 2 & 1 & 1 & 1 \\
Wind plant capacity(MW) & 1.2 & 0.9 & 1.0 & 1.5 \\
Estimated energy delivered(MWh) & 4437 & 3200 & 4005 & 3287 \\
Total initial costs(US\$) & $2,186,195$ & $1,703,198$ & $2,245,396$ & $2,363,578$ \\
Operating cost (US\$) & 185,344 & 174,115 & 185,093 & 175,309 \\
Project equity & 655,859 & 510,960 & 673,619 & 709,073 \\
Project debt & $1,530,337$ & $1,192,239$ & $1,571,777$ & $1,654,504$ \\
Debt Interest rate & 8.5 & 8.5 & 8.5 & 8.5 \\
Debt term & 10 & 10 & 10 & 10 \\
Cost per kWh(UScents/kWh) & 6.15 & 7.57 & 6.86 & 8.21 \\
\hline
\end{tabular}

power capacities were investigated. Wind turbine with $1800 \mathrm{~kW}$ rated power capacity was not taken into the analysis due to over production. Percent capital cost breakdown is shown in Table 3. The operating and maintenance costs are 186,615 US\$ for $0.6 \mathrm{MW}$, 172,023 US\$ for $0.9 \mathrm{MW}, 181,819$ US\$ for $1 \mathrm{MW}, 176,384$ US\$ for $1.5 \mathrm{MW}$ and 207,957 US\$ for $1.8 \mathrm{MW}$ capacity wind turbines for this case. Table 4 shows the summary of all alternatives for this case. 


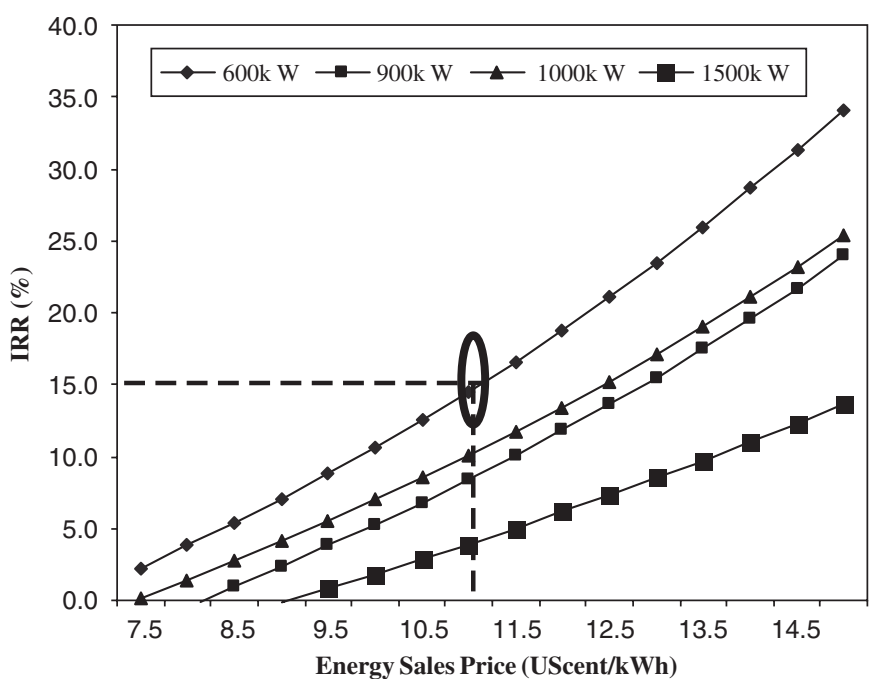

Fig. 5. IRR versus energy price for autoproducer scenario.

Table 5

Variance analysis summary for Enercon E40-600 kW

\begin{tabular}{llll}
\hline $\begin{array}{l}\text { Variable and variance } \\
\text { Base case }\end{array}$ & & IRR & $\begin{array}{l}15 \% \text { NPV } \\
\text { 15\% (US\$) }\end{array}$ \\
\hline Price & $-20 \%$ & $6.7 \%$ & $-506,097$ \\
& $+20 \%$ & $25.3 \%$ & 468,695 \\
Op cost & $-20 \%$ & $18.7 \%$ & 185,928 \\
Capital & $+20 \%$ & $11.6 \%$ & $-191,262$ \\
& $-20 \%$ & $23.1 \%$ & 304,863 \\
Inflation & $+20 \%$ & $10.3 \%$ & $-319,862$ \\
& $+2 \%$ & $12.3 \%$ & $-131,421$ \\
Debt & $+4 \%$ & $7.5 \%$ & $-296,147$ \\
& $30 \%$ & $12.1 \%$ & $-250,757$ \\
& $50 \%$ & $13.2 \%$ & $-124,065$ \\
\multirow{3}{*}{ Repayment } & $70 \%$ & $15.0 \%$ & 0 \\
& $90 \%$ & $18.8 \%$ & 121,752 \\
& 1 year & $11.5 \%$ & $-342,659$ \\
& 6 years & $13.1 \%$ & $-131,042$ \\
& 10 years & $15 \%$ & 0 \\
& 12 years & $16.2 \%$ & 54,948 \\
\hline
\end{tabular}

IRR values were calculated versus different energy sales prices and compared with each other. For most of the energy projects, the required minimum IRR value is $15 \%$. It is seen from Fig. 5 that, wind turbine with $600 \mathrm{~kW}$ rated power has $11.12 \mathrm{UScents} / \mathrm{kWh}$ of energy sale price corresponding to this rate. After having established base case, it is important to determine the impact of the major cost components on the project. Therefore, an example of variance analysis is presented in Table 5. After selecting the proper wind turbine for a 
particular scenario, variance analysis is needed in order to find out the most effective parameters on the IRR and NPV values. The parameters, which are taken into account for this analysis are energy sales price, operating cost, capital cost, inflation rate, debt, and repayment period. Because those parameters are not certain and change the investment credibility.

As it is seen from Table 5, the most effective parameters are energy sales price and capital cost for this scenario. Repayment periods less than 10 years make this investment unattractive.

Revenue is the only positive component of the cash flow. It is largely determined by sales price. But the change in production has effect on it. Capital cost is an input at the very beginning of the project and has negative influence on the discounted cash flow. Operation cost exerts a strong impact on the cash flow, as well. Fig. 6 shows the sensitivity of these costs as IRR versus variance.

Discount and interest rates are also important parameters in the project evaluation. Figs. 7 and 8 presents NPV and IRR relationships versus discount and interest rates, respectively.

\subsubsection{Autoproducer group case}

The autoproducer group's annual energy consumption was about 6,500,000 kWh. For this case study, another governmental facility was cooperated with the Institute. Percent capital cost breakdown is shown in Table 6. The operating and maintenance costs are 209,202 US\$ for 0.6 MW, 206,202 US\$ for 0.9 MW, 225,259 US\$ for $1 \mathrm{MW}, 213,648$ US\$ for $1.5 \mathrm{MW}$ and $207,957 \mathrm{US} \$$ for $1.8 \mathrm{MW}$ capacity wind turbines for this case. Table 7 shows the summary of all alternatives for this case.

Since the capacity of the farm did not change too much, the amount of money invested on feasibility, development, and engineering components were taken the same as autoproducer case.

It is seen from Fig. 9 that, wind turbine with $900 \mathrm{~kW}$ rated power had 9.08 US cents/ $\mathrm{kWh}$ of energy sales price corresponding to the base IRR of $15 \%$. Variance analysis is presented in Table 8 for this scenario. It is seen that, the most effective parameters are

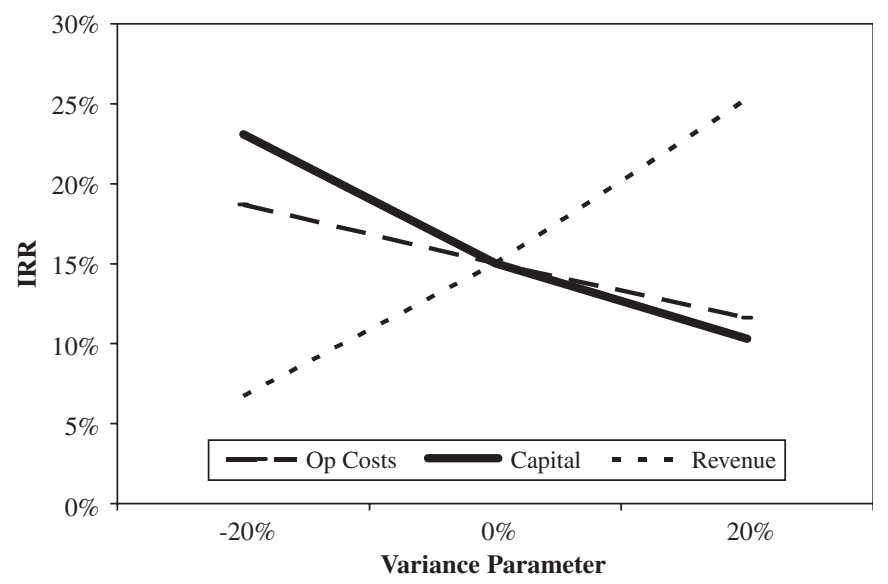

Fig. 6. Sensitivity graph for autoproducer scenario. 


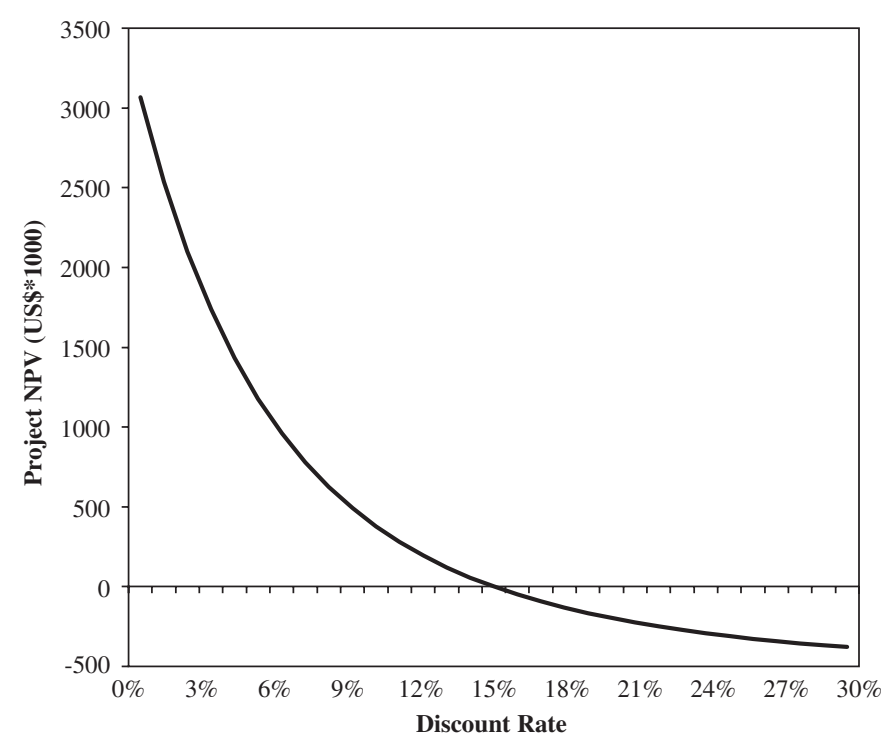

Fig. 7. NPV versus discount rate for autoproducer scenario.

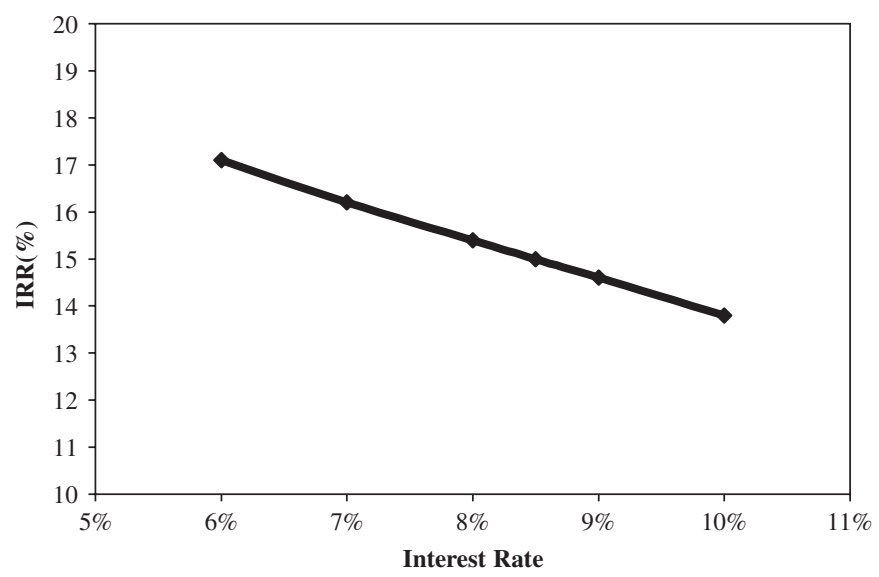

Fig. 8. IRR via debt interest rate for autoproducer scenario.

energy sales price and capital cost for this scenario too. Repayment periods less than 10 years are also unattractive.

\subsubsection{Independent power producer case}

Under the land and grid considerations, the installed capacity of the IPP case was $12 \mathrm{MW}$ at most. Similar calculations and evaluations were made for the third scenario. Percent capital cost breakdown is shown in Table 9. The operating and maintenance costs are 581,200 US\$ for $0.6 \mathrm{MW}, 552,523$ US\$ for $0.9 \mathrm{MW}, 619,506$ US\$ for $1 \mathrm{MW}$, 394,115 US\$ for 1.5 MW and 589,941 US\$ for 1.8 MW capacity wind turbines for this case. Table 10 shows the summary of all alternatives for this case. 
Table 6

Capital cost break down for autoproducer group scenario (US\$)

\begin{tabular}{|c|c|c|c|c|c|c|c|c|c|c|}
\hline \multirow{2}{*}{$\begin{array}{l}\text { WECS } \\
\text { Item }\end{array}$} & \multicolumn{2}{|l|}{$0.6 \mathrm{MW}$} & \multicolumn{2}{|l|}{$0.9 \mathrm{MW}$} & \multicolumn{2}{|l|}{$1 \mathrm{MW}$} & \multicolumn{2}{|l|}{$1.5 \mathrm{MW}$} & \multicolumn{2}{|l|}{$1.8 \mathrm{MW}$} \\
\hline & Cost & $\%$ & Cost & $\%$ & Cost & $\%$ & Cost & $\%$ & Cost & $\%$ \\
\hline Equipment & $2,004,520$ & 68.89 & $1,802,520$ & 67.57 & $2,835,208$ & 75.57 & $3,052,480$ & 76.54 & $2,099,540$ & 71.31 \\
\hline Feasibility & 40,600 & 1.40 & 40,600 & 1.52 & 40,600 & 1.08 & 40,600 & 1.02 & 40,600 & 1.38 \\
\hline Development & 157,000 & 5.40 & 157,000 & 5.89 & 157,000 & 4.18 & 157,000 & 3.94 & 157,000 & 5.33 \\
\hline Engineering & 36,100 & 1.24 & 36,100 & 1.35 & 36,100 & 0.96 & 36,100 & 0.91 & 36,100 & 1.23 \\
\hline Balance of plant & 553,000 & 19.00 & 522,000 & 19.57 & 532,000 & 14.18 & 542,000 & 13.59 & 491,000 & 16.68 \\
\hline Miscellaneous & 118,649 & 4.08 & 109,329 & 4.10 & 151,036 & 4.03 & 160,127 & 4.01 & 119,970 & 4.07 \\
\hline
\end{tabular}

Table 7

Summary of all alternatives for autoproducer group scenario

\begin{tabular}{|c|c|c|c|c|c|}
\hline Autoproducer group & 1 & 2 & 3 & 4 & 5 \\
\hline Turbine-rated power(kW) & 600 & 900 & 1000 & 1500 & 1800 \\
\hline Manufacturer/turbine type & Enercon E40 & NEG-Micon NM52 & Enercon E58 & NEG-Micon NM64 & Enercon E66 \\
\hline Number of turbines & 3 & 2 & 2 & 2 & 1 \\
\hline Wind plant capacity (MW) & 1.8 & 1.8 & 2.0 & 3.0 & 1.8 \\
\hline Estimated energy delivered (MWh) & 6655 & 6399 & 8011 & 6574 & 6458 \\
\hline Total initial costs (US\$) & $2,909,869$ & $2,667,549$ & $3,751,944$ & $3,988,307$ & $2,944,210$ \\
\hline Operating cost (US\$) & 221,191 & 202,017 & 234,427 & 215,798 & 202,677 \\
\hline Project equity & 872,961 & 800,265 & $1,125,583$ & $1,196,492$ & 883,263 \\
\hline Project debt & $2,036,908$ & $1,867,284$ & $2,626,361$ & $2,791,815$ & $2,060,947$ \\
\hline Debt Interest rate & 8.5 & 8.5 & 8.5 & 8.5 & 8.5 \\
\hline Debt term & 10 & 10 & 10 & 10 & 10 \\
\hline Cost per kWh (UScents/kWh) & 5.07 & 4.82 & 4.80 & 5.71 & 4.96 \\
\hline
\end{tabular}

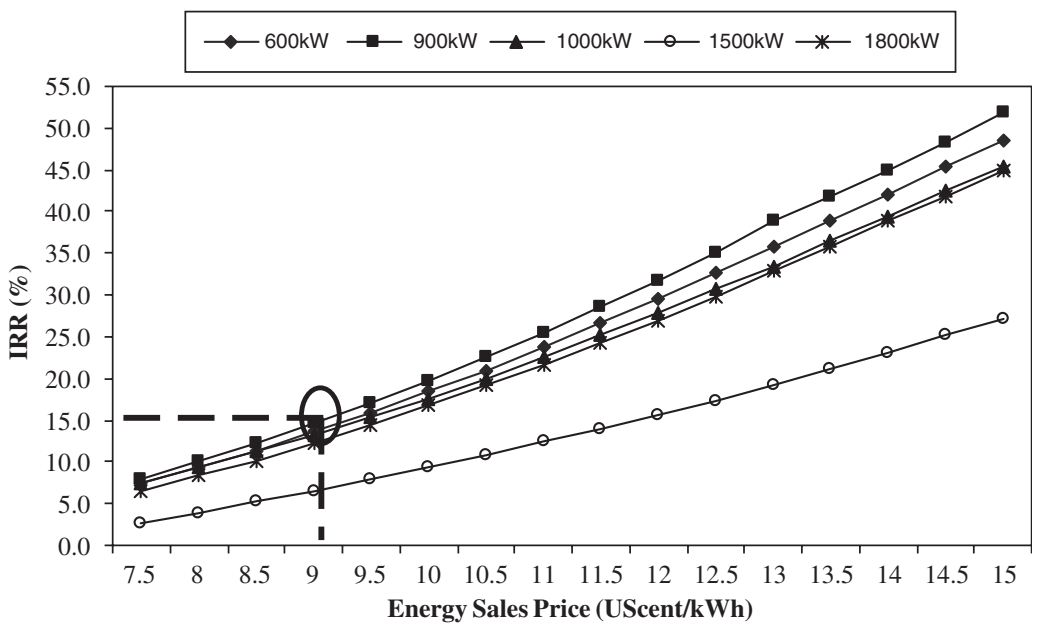

Fig. 9. IRR versus energy price for autoproducer group scenario. 
Table 8

Variance analysis summary for NM52-900 kW.

\begin{tabular}{llll}
\hline $\begin{array}{l}\text { Variable and variance } \\
\text { Base case }\end{array}$ & & IRR & $\begin{array}{l}15 \% \text { NPV } \\
0(\text { US } \$)\end{array}$ \\
\hline Price & & $15 \%$ & $-596,828$ \\
Op cost & $-20 \%$ & $7 \%$ & 550,874 \\
& $+20 \%$ & $24.9 \%$ & 204,676 \\
Capital & $-20 \%$ & $18.4 \%$ & $-213,214$ \\
& $+20 \%$ & $11.9 \%$ & 390,183 \\
Inflation & $-20 \%$ & $23.6 \%$ & $-408,245$ \\
& $+20 \%$ & $10.2 \%$ & $-145,401$ \\
Debt & $+2 \%$ & $12.6 \%$ & $-327,393$ \\
& $+4 \%$ & $8.5 \%$ & $-305,968$ \\
& $30 \%$ & $12.1 \%$ & $-151,382$ \\
& $50 \%$ & $13.2 \%$ & 0 \\
Repayment & $70 \%$ & $15 \%$ & 148,559 \\
& $90 \%$ & $18.8 \%$ & $-418,106$ \\
& 1 year & $11.5 \%$ & $-159,895$ \\
& 6 years & $13.1 \%$ & 0 \\
\hline
\end{tabular}

Table 9

Capital cost break down for IPP scenario (US\$)

\begin{tabular}{|c|c|c|c|c|c|c|c|c|c|c|}
\hline \multirow{2}{*}{$\begin{array}{l}\text { WECS } \\
\text { Item }\end{array}$} & \multicolumn{2}{|l|}{$0.6 \mathrm{MW}$} & \multicolumn{2}{|l|}{$0.9 \mathrm{MW}$} & \multicolumn{2}{|l|}{$1 \mathrm{MW}$} & \multicolumn{2}{|l|}{$1.5 \mathrm{MW}$} & \multicolumn{2}{|l|}{$1.8 \mathrm{MW}$} \\
\hline & Cost & $\%$ & Cost & $\%$ & Cost & $\%$ & Cost & $\%$ & Cost & $\%$ \\
\hline Equipment & $13,146,800$ & 82.34 & $11,506,380$ & 82.01 & $16,821,248$ & 85.94 & $12,099,920$ & 83.50 & $14,466,780$ & 85.44 \\
\hline Feasibility & 59,000 & 0.37 & 59,000 & 0.42 & 59,000 & 0.30 & 59,000 & 0.41 & 59,000 & 0.35 \\
\hline Development & 390,500 & 2.45 & 390,500 & 2.78 & 390,500 & 2.00 & 390,500 & 2.69 & 390,500 & 2.31 \\
\hline Engineering & 158,000 & 0.99 & 158,000 & 1.13 & 158,000 & 0.81 & 158,000 & 1.09 & 158,000 & 0.93 \\
\hline Balance of Plant & $1,590,000$ & 9.96 & $1,368,000$ & 9.75 & $1,382,000$ & 7.06 & $1,218,000$ & 8.40 & $1,197,000$ & 7.07 \\
\hline Miscellaneous & 622,772 & 3.90 & 548,275 & 3.91 & 761,430 & 3.89 & 566,017 & 3.91 & 659,851 & 3.90 \\
\hline
\end{tabular}

Table 10

Summary of all alternatives for IPP scenario

\begin{tabular}{llllll}
\hline IPP & 1 & 2 & 3 & 4 & 5 \\
\hline Turbine-rated power (kW) & 600 & 900 & 1000 & 1500 & 1800 \\
Manufacturer/turbine type & Enercon E40 & NEG-Micon NM52 & Enercon E58 & NEG-Micon NM64 & Enercon E66 \\
Number of turbines & 20 & 13 & 10 & 8 & 7 \\
Wind plant capacity (MW) & 12.0 & 11.7 & 12.0 & 12.0 & 12.6 \\
Estimated energy delivered (MWh) & 44,365 & 41,596 & 48,064 & 26,298 & 45,209 \\
Total initial costs (US\$) & $15,967,072$ & $14,030,155$ & $19,572,178$ & $14,491,437$ & $16,931,131$ \\
Operating cost (US\$) & 581,200 & 552,523 & 619,506 & 394,115 & 589,941 \\
Project equity & $4,790,122$ & $4,209,047$ & $5,871,653$ & $4,347,431$ & $5,079,339$ \\
Project debt & $11,176,950$ & $9,821,109$ & $13,700,525$ & $10,144,006$ & $11,851,792$ \\
Debt interest rate & 8.5 & 8.5 & 8.5 & 8.5 & 8.5 \\
Debt term & 10 & 10 & 10 & 10 & 10 \\
Cost per kWh (Uscents/kWh) & 2.75 & 2.68 & 2.92 & 3.70 & 2.80 \\
\hline
\end{tabular}




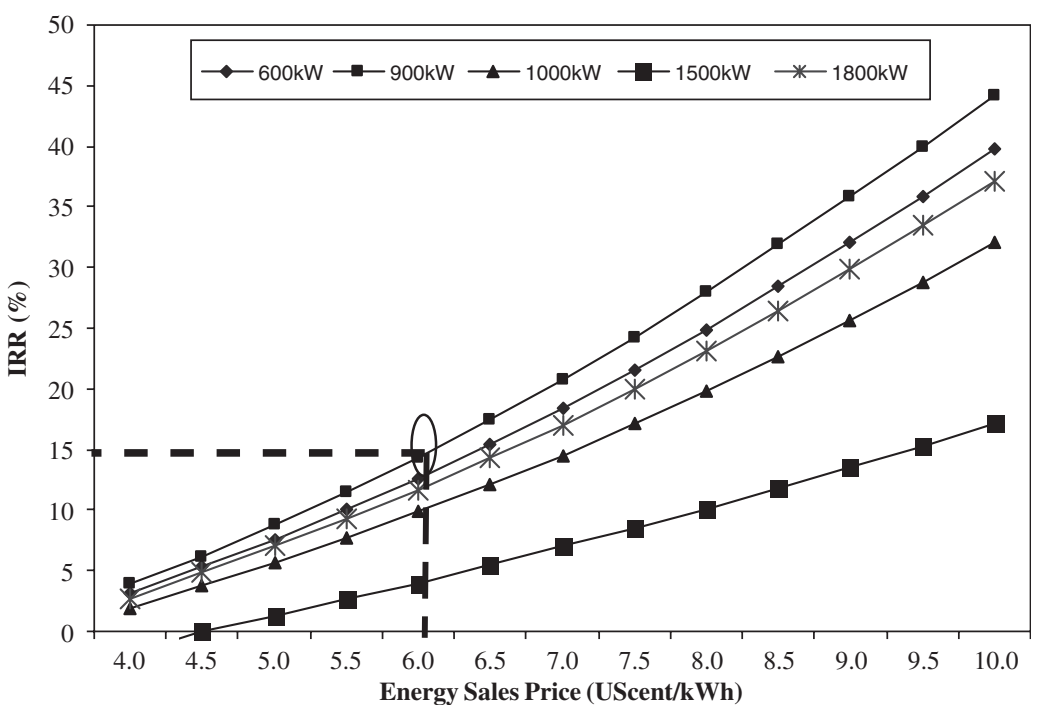

Fig. 10. IRR versus energy price for IPP scenario.

Table 11

Variance analysis summary for NM52-900 kW

\begin{tabular}{llll}
\hline $\begin{array}{l}\text { Variable and variance } \\
\text { Base case }\end{array}$ & & $\begin{array}{l}\text { IRR } \\
15 \%\end{array}$ & $\begin{array}{l}15 \% \text { NPV } \\
0 \text { (US\$) }\end{array}$ \\
\hline Price & $-20 \%$ & $8.2 \%$ & $-2,587,913$ \\
& $+20 \%$ & $23.1 \%$ & $2,434,692$ \\
Op cost & $-20 \%$ & $16.7 \%$ & 572,104 \\
Capital & $+20 \%$ & $13.3 \%$ & $-580,104$ \\
& $-20 \%$ & $23.6 \%$ & $2,061,582$ \\
Inflation & $+20 \%$ & $10.3 \%$ & $-2,053,424$ \\
& $+2 \%$ & $13.8 \%$ & $-400,337$ \\
Repayment & $+4 \%$ & $12.1 \%$ & $-897,817$ \\
& 1 year & $11.5 \%$ & $-2,199,047$ \\
& 6 years & $13.1 \%$ & $-840,967$ \\
& 10 years & $15 \%$ & 0 \\
& 12 years & $16.2 \%$ & 352,641 \\
\hline
\end{tabular}

It is seen from Fig. 10 that, wind turbine with $900 \mathrm{~kW}$ rated power had 6.12 UScents/ $\mathrm{kWh}$ of energy sales price corresponding to the base IRR value of $15 \%$. As it is seen from variance analysis study, which is presented in Table 11 for this scenario, the most effective parameters are energy sales price and capital cost. Repayment periods less than 10 years are unattractive, as well.

\section{Conclusion}

In this article, a technical and economical feasibility study of wind farm alternatives to a selected site in Izmir, Turkey has been proposed. Because of high wind resource capacity, 
Table 12

Comparison of three cases studied.

\begin{tabular}{llll}
\hline Status & Autoproducer & Autoproducer group & $\begin{array}{l}\text { Independent power } \\
\text { producer (IPP) }\end{array}$ \\
\hline Turbine type & Enercon E40-600 kW & NEG-Micon & NEG-Micon \\
& & NM52-900 kW & NM52-900 kW \\
Wind plant capacity (MW) & 1.2 & 1.8 & 11.7 \\
Estimated energy delivered (MWh) & 4437 & 6399 & 41,596 \\
Total initial cost & $2,186,195$ & $2,667,549$ & $14,030,155$ \\
Cost per kWh (UScents/kWh) & 6.27 & 4.82 & 2.68 \\
\hline
\end{tabular}

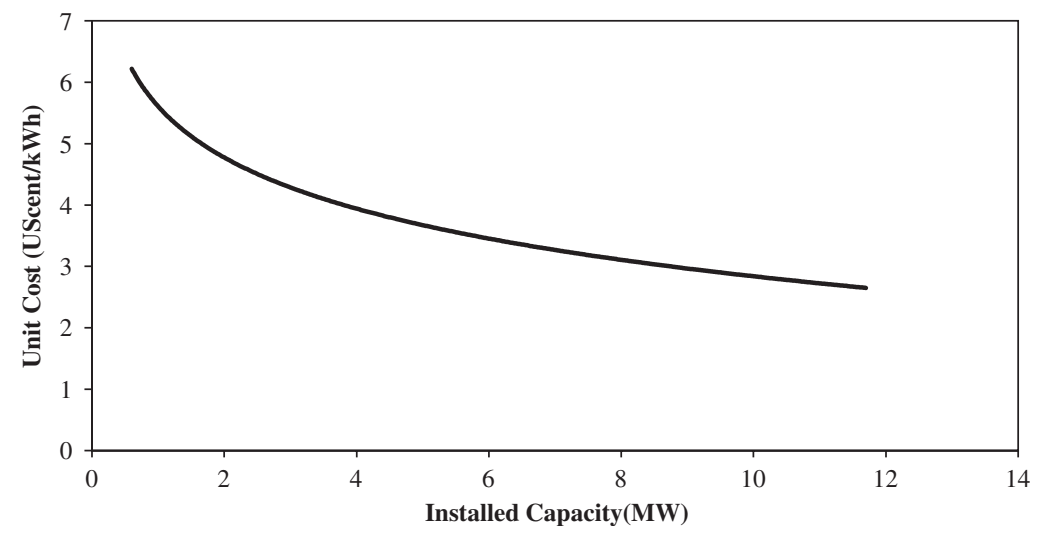

Fig. 11. Energy unit cost versus installed capacity.

the site has been classified as excellent. The site has been evaluated for the unit cost of electricity produced by each alternative, as well. The influence of each main cost parameter has been estimated. The illustration has been done for three scenarios, namely autoproducer, autoproducer group and independent power producer (IPP) cases. According to the results, it can be concluded that the projects were more feasible for autoproducer, autoproducer group, and IPP cases with 600, 900, and again $900 \mathrm{~kW}$ rated power wind turbines, respectively. All three scenarios are promising in respect to generating cost per $\mathrm{kWh}$ and IRR value. But the most suitable scenario has been found as $I P P$ case. Table 12 compares the three cases in terms of turbine type, plant capacity, energy delivered, initial cost, and unit cost of energy generated. Fig. 11 also shows the variation of generating cost per $\mathrm{kWh}$ versus installed power capacity. The results have indicated that, the larger the installed capacity, the smaller the generating cost per $\mathrm{kWh}$. It has been shown that, the generating cost could be as low as $2.68 \mathrm{UScent} / \mathrm{kWh}$ in the IPP scenario for 11.7 MW installed capacity. The profitability analysis has shown that, larger installed capacity with larger rated power wind turbines present higher IRR value for the investment. Variance analysis studies have concluded that, the most effective parameters are energy sales price and capital cost for the proposed scenarios. Repayment periods less than 10 years are found unattractive. The sensitivity analysis study has backed up these findings, as well. 
Despite encouraging growth forecasts, private investment in the renewable energy sector is currently very modest and limited. The industry is still heavily dependent on government and public funding. Therefore, incentive policies are essential for the commercialization of renewable energy. In general, these incentives can be public funds for research and development, direct support of investment costs, price support for electricity from renewable resources, favorable interest rates, and tax incentives.

\section{References}

[1] National Wind Energy Coordinating Committee, Permitting Wind Energy Facilities-A Handbook, NWCC Siting Subcommittee, www.nationalwind.org, March 1998.

[2] A. Pantaleo, A. Pellerano, F. Ruggiero, M. Trovato, Feasibility study of off-shore wind farms: an application to Puglia region, Sol. Energy 79 (2005) 321-331.

[3] K.M. Stockton, Utility-scale wind on islands: an economic feasibility study of Ilio Point, Hawaii, Renew. Energy 29 (2004) 949-960.

[4] M.A.H. El-Sayed, Substitution potential of wind energy in Egypt, Energy Policy 30 (2002) 681-687.

[5] A. Marafia, H.A. Ashour, Economics of off-shore/on-shore wind energy systems in Qatar, Renew. Energy 28 (2003) 1953-1963.

[6] W. El-Osta, Y. Kalifa, Prospects of wind power plants in Libya: a case study, Renew. Energy 28 (2003) 363-371.

[7] F. Cavallaro, L. Ciraolo, A multicriteria approach to evaluate wind energy plants on an Italian island, Energy Policy 33 (2005) 235-244.

[8] J.K. Kaldellis, An integrated time-depending feasibility analysis model of wind energy applications in Greece, Energy Policy 30 (2002) 267-280.

[9] EWEA and Greenpeace, Wind Force 12: A blueprint to achieve 12\% of the World's electricity from Wind Power by 2020, www.awea.org, 2002.

[10] R. Gross, M. Leach, A. Bauen, Progress in renewable energy, Environ. Int. 987 (2002) 1-18.

[11] N. Hatziargyriou, A. Zervas, Wind power development in Europe, Proc. IEE 89 (2001) 1765-1782.

[12] Global Wind Energy Council, Global Wind Energy Markets, www.gwec.net, March 2005.

[13] Republic of Turkey, Prime Ministry State Institute of Statistics, www.die.gov.tr, March 2005.

[14] US Department of Energy-Office of Fossil Energy, An Energy Overview of the Republic of Turkey, www.fossil.energy.gov, February 2005.

[15] National Renewable Energy Laboratory, Wind Resource Assessment Handbook, April 1997.

[16] WAsP User's Guide, www.risoe.dk.

[17] WindPro Software, Ver. 2.1, www.emd.dk.

[18] WAsP Software, www.wasp.dk.

[19] MesoMap Software, www.awstruewind.com.

[20] D. Scanlin, X. Li, C. Larson, Wind Farm Siting, North Caroline Wind Summit, 2002.

[21] RETScreen Software, www.retscreen.net.

[22] Product Data, www.retscreen.net, March 2004. 